\title{
A Study on Students Academic Reasons in the Thesis Background
}

\author{
Sri Minda Murni \\ Dept. English Applied Linguistics \\ Universitas Negeri Medan \\ Medan, Indonesia \\ srimindamurni@gmail.com
}

\author{
Mutsyuhito Solin \\ Dept. Indonesian Education \\ Universitas Negeri Medan \\ Medan, Indonesia \\ mutsyuhito@yahoo.co.au
}

\begin{abstract}
Students' poor academic reasons in the background of their thesis have been a big concern among the supervisors. A good thesis background presents previous research findings as the conceptual foundation of the study and the preliminary data to show the gap, both are composed in a well-structured composition to fulfil its function. The research problems are: a) how are the previous research findings processed in the background?, b) how are the preliminary data processed? c) How are the informations in the background composed? The data was taken from theses produced by Applied Linguistics Study Program in the year of 2017. Thirteen theses were randomly selected. The results show that the academic reasons in their background are very weak. It is shown by the fact that: a) The backgrounds do not present a satisfying exploration on previous research results; b) The empirical evidences were not processed convincingly to enhance the existence of the gap to pursue; c) The backgrounds are not composed in an analytical exposition text types which comprise thesis, arguments, and reiteration. The result of the study will be useful as a resource material for supervisors in helping their students write a good thesis background.
\end{abstract}

Keywords - literacy competence; academic reason; previous research; preliminary data; analytical exposition, thesis background.

\section{INTRODUCTION}

A backgrond mainly consists of two components, they are background information and purposes [12]. In a more detailed version, six elements of the background are: (1) The broad theme or topic of the study, (2) The academic and practical importance, (3) The summary of literature and previous studies relevant to the current research, (4) The most important gaps, inconsistencies and/or controversies in the literature that the current study will address, (5) The core of the research problem/question, specific research objectives, the context the study and the unit of analysis of the study, and (6) The outline of the structure of the article [11]. Inexperienced writes always have problems with the introduction or the background section. Common mistakes found in the introduction section include: a) providing an extensive and detailed literature review, b) not stating the hypothesis of the objectives with clarity, and c) not providing focused information [7].
One of the most important things in writing a thesis background is literacy competence and sense making. Previous research finds out that students competence in making sense of information is very low. They suggest that "poor sense making literary skill have made our students become intelligent mass copy-paster". The low quality of students' sense of the information is represented as the following: (1) paraphrasing: 3 (15\%), (2) copy pasting: 17 (85\%), (3) referring to mainstream information:6 (30\%), and (4) referring to supporting information: $14(70 \%)$ [8].

Three main problems in the theses produced by students of Applied Linguistics Master Degree Program are dealing with their treatment on previous research findings, treatment on the preliminary data, and the composition. They are very important in justifying the significance of the study and in describing the unexplored areas, unanswered questions, and unresolved issues of the topic. The study will describe in detail common mistakes made by the students. The results of the study are expected to be used as a resource material for supervisors in guiding their thesis students.

\section{METHOD}

The source of data were the theses produced by English Applied Linguistics departments of the Master Degree Study Programs at the State University of Medan. Thirteen theses of different topics produced in the year of 2017 were randomly chosen. The data were taken from the abstract and the background. Long statements were simplified to get the focus and the main point, without changing the meaning and perspective.

\section{RESULTS}

The results show that the academic reasons the students composed in their background are very weak. It is shown by the fact that: a) The backgrounds do not present a satisfying exploration on previous research results; b) The empirical evidences were not processed convincingly to enhance the existence of the gap to pursue; c) The backgrounds are not composed in an analytical exposition text types which 
comprise thesis (the researcher's opinion), arguments (his/her elaboration of the oipnion), and reiteration (coclusion).

\section{A. The backgrounds do not present a satisfying exploration on previous research results}

A good background should present an explorative discussion on previous research results which are not only relevant to the topic but which are also judged as not yet representing the particular phenomenon of the researcher's interest. The unsatisfying exploration on previous research results is categorized into three categories, they are: a) The number of the previous researches are insufficient; b) The previous researches are irrelevant; and c) The previous researches are presented but ignored.

\section{1) The Number of the Previous Researches Are} Insufficient

The majority of the thesis backgrounds include definitions and descriptions and present very few relevant research-based articles. It is found that in average students only cite 2.2 previous research findings but quote 5.8 definitions. In addition, previous research covers $27.1 \%$ of the information in the background while definition covers $72.9 \%$. It implies that the backgrounds contain more definitions and elaborations rather than previous research findings.

\section{2) The Previous Researches Are Irrelevant}

Other finding shows that the previous researches are irrelevant to the topic of research. The example is as follows,

Abidin (2012) finds out that students' attitudes towards learning English is negative. Al-Zahrani (2008) proposed that the reason of such negative attitude might have been a reaction to the instructional and traditional techniques used by some of the English language teachers. Based on the information above and the phenomenon that most of the Mandailing teenagers use Javanese language rather than Mandailing language, the researcher thinks that there must be something that influences the attitude of Mandailingese Teenagers in Desa Sidojadi Kecamatan Bukit Malintang Kabupaten Mandailing Natal [4].

As observed in the example, the previous research finding deals with negative language attitude toward English as the result of poor teaching and learning process. This issue is not relevant to the study of negative attitude of the teenagers toward Mandailingese since the issue in the later is not about teaching and learning but the interaction with other ethnic groups. This makes the previous research finding is not quite relevant.

\section{3) The Previous Researches Are Insufficiently Processed}

Other example shows that the previous researches are just 'listed' and not discussed. The example is as follows,

Izadi and Zilaie (2012) indicate that positive politeness strategy "group identity markers" and "give gifts to $\mathrm{H}$ " were the most dominant strategies in the Persian email exchanges. Mu (2015) finds out that
English reviewers used politeness strategies more frequently than Chinese reviewers. Those differences may be caused by several possible reasons, including three main aspects: cultural differences, different educational style, and different language systems. The two journals above have given contribution on the theory of politeness to this research with the different object [10].

In the example, it is observed that the researcher does not elaborate the two previous studies so show the possible interrelation or controversies between them. As the result, description on the area they have covered is not well mapped, so as the area they do not yet cover. The final sentence does not provide any argument that by studying 'different object' potential new knowledge in the topic will be obtained.

\section{B. The Preliminary Data or Empirical Evidences Are Not Processed Convincingly To Enhance the Existence of the Gap to Pursue}

Other weaknesses found in the thesis background deals with the researcher's treatment of the preliminary data or the empirical evidences. Theoretically, the preliminary data are used as a comparison and/or contrast to the previous research findings or to the existing theories. By comparing the two, the researcher will know what is lack in the previous research findings, the one he/she will pursue in his/her research. In addition, the preliminary data are used to convince the reader on how problematic the situation is. In addition, the example of detailed analysis on the preliminary data in the background is aimed at convincing the reader that new knowledge will be obtained in the end of the study.

The results show three categories of inefficiency and carelessness in treating the preliminary data. They are :a) The preliminary data is insufficiently processed, and b) The preliminary data is irrelevant.

\section{1) The Preliminary Data are Insufficiently Processed}

In the example below, the preliminary data are presented but insufficiently processed. The example is as follows,

Buyer: Au boru Purba to. Dari Doloksanggul.

Seller : Bah, marpariban do hita. Mamak ku pun manalu juga.

Buyer : Itulah, jangan celit-celit sama pariban

Seller : Yodah 35 ribu ajalah

Buyer : Mauliate da pariban na burju. Baik kali lah.

The writer decides to study code-switching in communicative events between buyers and sellers in traditional market to know the reasons for the use of codeswitching [2].

As observed in the example, there is no elaboration on how such data show the gap with previous research findings or clarify the existence of new phenomenon. The existence of code switching will always be there in the language use; however it can not be used as a good academic reason to study the topic. Only by showing that the preliminary data have new 
characteristics compared to the ones found in the previous research findings then these data will be useful as a good academic reason.

\section{2) The Preliminary Data Do not Signal New Findings}

Many times the data do not provide any sign for new findings. The following example is as follows,

ST: Therapy should be continued in case contradiction is discovered.

TT: Terapi harus dihentikan saat ditemukan kontradiksi.

In the sample above, the translator used direct translation procedure which is borrowing [6].

The example shows that the presentation of the preliminary data is not to argue the possibility of obtaining new finding compared to the previous research results.

\section{3) No Preliminary Data}

The data also show that the thesis background does not consist of any preliminary data. One of the example [1] shows that there are five types of disruptions in children's (with language disorder) utterances. However, the preliminary data of those disorders are not introduced in her thesis background. The backround does not provide any previous research neither.

\section{The Backgrounds are Not Structurally Composed.}

1) The Analytical Exposition Generic Structure is Not Applied

Ideally, the backgrounds should present analytical exposition text type with the generic structure comprises thesis, arguments, and reiteration. The data show that the logic of analytical exposition is not applied. The example is as follows,

Moves in advertisements are also interesting to discuss. Nowadays, lots of advertisements are found includes in magazine. The advertisers design the advertisement creatively so the buyers buy the product they sell. Moves will help make the words put together nicely. The most important purpose of advertisement is to persude them to believe what is being advertised [13].

The first sentence is the student's thesis or opinion that studying advertisements is interesting to do. However she does not support the thesis by providing some relevant arguments on why it is interesting.

Another example is as follows,

It is clear that the politeness shift had occured in the Javanese community in Subussalam. Every level of Javanese language has its own politeness. Krama politeness is the most polite one while Ngoko politeness is the lowest. So it is not polite if Ngoko politeness is used by younger generation to their elders [3].
The student introduces the phenomenon of the shift in which younger generation use Ngoko instead of Krama to their elders. However, the thesis is not followed by arguments such as the example of the Ngoko utterance used by the teenagers and how they have been perceived as politeness shift.

The third example is as the following,

The researcher is interested in analyzing the translation procedure in patient information leaflets as first, it is the translation product issued by pharmaceutical company that has very important function...Second, the research on translation of medical or technical text is more needed nowadays as the development of technology and science...Third, there are many problems in translation especialy in translating scientific or technical text because... [6].

The thesis in the example is that the student is interested in analyzing translation procedure applied in the patient information leaflets. However the thesis is not supported by argumentsThe arguments ltion procedure. shows that the arguments for the researcher's interest in studying

\section{2) No Analytical Exposition is Presented}

Another case shows that the background does not present any thesis (opinion) in which the student researcher clarifies how important the topic she/he studies.

Example is as follows,

Based on the previous studies above, the writer is interested in anayzing the figurative language used in Saur Matua ceremony. The writer hopes that the study will give contributions to ... [5].

In the example, the writer does not describe why anayzing figurative language in the ceremony is important for linguitic fields.

\section{Discussions}

Writing an academic text is different from free writing. Academic text requires knowledge of the text structure, the skills in writing within the structure, and the ethics. As observed in the thesis background, students are not familiar with the structure of the text. A background is the presentation of academic reasons for a researcher to study a topic, so the logical structure should follow an analytical exposition text type, i.e thesis statement (opinion) followed by arguments and reiterations. Most of the students fail in fulfilling the structure requirement. Eventhough all of the thesis background contains a promising thesis statement such as 'The writer is interested in anayzing...' however there is no strong argument that follow. To our surprise, most of the thesis statement followed by their care for others such as the example 'The writer is interested in anayzing the .... The writer hopes that the study will give contributions to ...' which is more to acknowledgement rather than academic reasons. 
Writing is a complex cognitive activity. The more someone reads the better she/he writes. An academic writing requires a lot of reading on academic texts. The thesis backgrounds written by the student reseachers reflect poor reading performance both in quantity and quality. If the number of the research-based articles read by the students found to be very low, the number they are able to comprehend even fewer. As observed in the data, previous researches are reported just on the surface level and on very few aspects which implies that students do not obtain the most important or leading informations as suggested in the IMRaD (Introduction, Method, Results, and Discussion) (Murni and Solin, 2013a). In addition, the individual previous research is listed without any elaboration on how they are interrelated one to another and the explorations of the controversies between definitions as well research results are more likely to be impossible. Poor competence in comprehending a researchbased article is also due to inability to approach the text with the same structure between the mind and the text. An academic text will be incomprehensible if it is approached through the structure of mind of for example narrative text. So the internalization of the structure of academic text as well as the internalization on how informations composed are absolute requirements for a student researcher. From some empirical evidences, it is found out that practicing to conduct IMRaD analysis on research-based articles is very significant in improving students' comprehension on the research-based article as well as on their writing competence [9].

The worksheet designed for students Practicing IMRaD analysis is presented as follows,

\section{TABLE I. WORKSHEET FOR IMRAD ANALYSIS}

\begin{tabular}{|l|l|l|l|l|}
\hline No & Introduction & Method & Results & Discussion \\
\hline & & & & \\
& & & & \\
& & & & \\
\hline
\end{tabular}

The students' incompetence also covers the area of ideas engineering. Idea engineering helps a student researcher to compare and contrast between previous researches and the particular phenomenon he/she is trying to describe. Murni, et.al 2013 for example have found that there are three kinds of politeness strategies used by cross gender relatives. Practicing on what potential topic to pursue for that research is a good training for students to conduct ideas engineering. When a student researcher present his/her preliminary data, it implies that he/she is showing arguments on the limitation of the previous research results he/she quoted previously. Through the preliminary data he/she is convincing the readers that new knowledge will be obtained in the research he is conducting. The preliminary data shown by the student researchers in the thesis background absolitely not the result of ideas engineering process. That is the main reason for the preliminary data are not elaborated to clarify the purpose of the research.
The worksheet designed for students Practicing Ideas Engineering is presented as follows,

\section{TABLE II. WORKSHEET FOR IDEAS ENGINEERING}

\begin{tabular}{|l|l|l|l|l|l|}
\hline No & $\begin{array}{l}\text { Previous } \\
\text { article }\end{array}$ & $\begin{array}{l}\text { Research } \\
\text { Results }\end{array}$ & $\begin{array}{l}\text { Preliminary } \\
\text { Data }\end{array}$ & Reasons & $\begin{array}{l}\text { Ideas } \\
\text { Engineering }\end{array}$ \\
\hline & & & & & \\
& & & & & \\
\hline
\end{tabular}

The worksheet for practicing ideas engineering will help students to train their creative ideas on in exploring new area of study in the topic they would like to pursue.

To conclude, writing a good background for a thesis requires a series of previous practices and trainings through assignments and classroom tasks of high order thinking quality. By those trainings which include the 6 types of tasks, the students cognition and mastery of the topic will improve and achieve its best result as pictured in the thesis.

\section{Acknowledgment}

The writers would like to extend their gratitudes to the students who involved in the research through the theses they have submitted. The writers would also like to express their appreciation to the students who attended their classes and really worked hard to fulfil the requirement of the six task assigned for them, i.s Routin task, Critical Journal Review, Critical Book review, Ideas Engineering, Mini-Research, and Projects.

\section{References}

[1] D. Wardani, "Disruption in Children with Language Disorder," Unpublished.

[2] J. Siburian, "Code Switching in Communicative Events Between Buyers and Sellers in Traditional Market," Unpublished.

[3] Karyanto, "Javanese language Shift in Subulus Salam," Unpublished.

[4] L.F. Hasibuan, "Language Attitude of Mandailingnese Teenagers in Desa Sidojadi Kecamatan Bukit Malintang Kabupaten Mandailing Natal," Unpublished.

[5] M. Tampubolon, "Figurative Language in The Toba Batak Saur Matua Ceremony," Unpublished.

[6] Rahmawati, "Translation Procedures in Patient Information Leaflet," Unpublished.

[7] S.B. Bavdekar, "Writing Introduction: Laying the Foundations of a Research Paper," Journal of the Associations of the Physicians of India, vol 63, pp.44-46, July 2015.

[8] S.M. Murni, and M. Solin, "Literacy and Sense Making," Jurnal Tabularasa PPS Unimed, vol 10, no 2, pp. 179-187, Agustus 2013.

[9] S.M. Murni, and M. Solin, "Imrad and Navigating Students Way Around Literature," Jurnal Linguistik Terapan, vol 10 (2). pp. 109-246, 2013.

[10] T. Iswati, "Politeness Strategy Used by The Antagonist and The Protagonist Characters In "The Silence of The Lambs" (A Pragmatics Study)," Unpublished.

[11] T. Kotze, "Guidelines on Writing A First Quantitative Academic Article", Department of Marketing and Communication Management, University of Pretoria, 2nd ed., 2007. 
[12] P. WCG, and KH. Ng, "Effective Medical Writing. Pointers to Getting Your Article Published", Singapore Medical Journal, vol 49 (10). pp. 756-758, 2008.

[13] V.N. Siregar, "Move Analysis in Cosmetic Advertisements in Women's Weekly Magazines," Unpublished. 